\title{
AZ ÖKOLÓGIAI FENNTARTHATÓSÁGRA NEVELÉS ÚJ LEHETŐSÉGEI ÉS AKADÁLYAI A FELSŐOKTATÁSBAN
}

\section{Miklós Attila}

Szent István Egyetem, Gazdaság- és Társadalomtudományi Kar, Társadalomtudományi és Tanárképző Intézet, Oktatásmódszertan és Romológia Tanszék

\section{Környezeti nevelési célok és követelmények érvényesülése a felsőoktatásban}

Az ökológiai fenntarthatóságra nevelés - éppúgy, mint általában minden környezeti szemléletformálást, illetve tudásfejlesztést szorgalmazó intézkedéscsomag - a kompetenciaalapú oktatásra épít. Ezen megállapítás nemcsak közoktatási rendszerünkre, hanem a magyar felsőoktatásra is vonatkozik: fontos ugyanakkor megjegyezni, hogy utóbbi esetében mind a megvalósítás, mind a számon kérhetőség sikere számos olyan akadályba ütközik, amelyek áthidalására a mai napig nem találtunk megoldást. Ennek elsősorban nem pszichológiai, pedagógiai vagy más (diszciplináris) jellegü oka van, hanem alapvetően „közigazgatásieljárási" vagy szakpolitikai: tekintettel arra, hogy az állam a 18. életévüket betöltötteket felnőtt korúnak tekinti, ezen időponttól fogva „leveszi a kezét” nevelésükről, s minden olyan eljárást, amely a felnőttek oktatását-nevelését, fejlesztését, illetve ezek hatékonyságának ellenőrzését célozza, fakultatív jellegü tevékenységnek tekint. Ez azt jelenti - s így talán nem is meglepö -, hogy a környezeti célok és követelmények érvényesülése kapcsán egyelöre nem rendelkezünk túl jó eredményekkel (s azokra építő reformokkal sem).

A környezeti gondolkodás ügyét valamilyen módon érintő, $\mathrm{s}$ az intézményesített oktatásban megvalósítani hivatott tartalmi szabályozási rend általában a személyes kompetencia (egészséges és kulturált életmódra nevelés), valamint a szociális kompetencia (segítő életmódra nevelés) fejlesztését tüzi ki célul (Lükö, 2003). Fontos ugyanakkor olyan kompetenciaelemekre is fókuszálni, amelyek meghatározójává vagy akár közvetlen felelősévé válhatnak a környezeti szemlélet alakulásának. Ilyenek a rendszerszemléletü, a kritikai és a kreatív gondolkodás; a fenntartható fejlődéssel kapcsolatos tudáselemek bővítése; a fenntartható fejlődést nem támogató döntések következményeinek és a globális, regionális, nemzeti és helyi környezeti problémák ismerete. Ide tartozik a környezeti problémák gazdasági, ökológiai és társadalmi következményeinek ismerete; a fenntartható fejlődés etikai dimenziójának tudatosítása és a nemzedékek közötti és nemzedékeken belüli szolidaritás és felelősség is (Varga, 2006).

Az ökológiai fenntarthatóságra nevelés ügye a különböző (föként környezetvédelmi jellegü) felsőoktatási képzésekben eddig alapvetően olyan oktatási tartalmakra próbált építeni, mint az erőforrásokkal való gazdálkodásban a mértékletesség; az elérhető legjobb technológiák használata; a gazdasági szerkezet átalakítására való törekvés és a lokalitás elve. Mi igazolja ezt? Elsősorban a képzések tantervei, azok logikai felépítése, szorosan követve a Képzési és 
Kimeneti Követelmények rendszerét, de megvizsgálva a tantárgyi tematikákat, a felsőoktatáshoz - s különösen a környezeti képzésekhez - kapcsolódó egyéb szakmai dokumentációkat (pl. Környezeti Fenntarthatósági Útmutató, MABjelentések stb.) lényegében ugyanezen következtetésre juthatunk. A társadalom és a szakma elvárásai is elsősorban a biológiai sokféleség csökkenésének és a szennyezések növekedésének megfékezésére, valamint az éghajlatváltozás hatásainak mérséklésére terjednek ki - ahol elsősorban a fogyasztás visszafogásán, az anyag- és energiahatékonyságon, az ökológiai vagy biogazdálkodáson, illetve a vidékfejlesztésen keresztül remélnek kézzelfogható eredményeket. A felsőoktatásban végzett környezeti szemlélet-vizsgálatok a fentieket megerősítik, így összességében meg kell állapítani, hogy a követelmények tekintetében igen világos kép rajzolódik ki. Ebből azonban nem következik, hogy az ökológiai fenntarthatóság e szempontok mentén biztosított lenne - s nemcsak a „végrehajtás” (nevelési feladatok) elmaradása, akadályozottsága miatt.

\section{Egy hiányzó szempont az ökológiai fenntarthatóság ügyében: az antropocentrizmus}

$\mathrm{Az}$ antropocentrizmus a természeti folyamatok müködésének, ökológiai összefüggéseknek, valamint az ember és természet kapcsolatának emberközpontú megközelítését, szinte minden esetben az emberi szempontokat és érdekeket előtérbe helyező gondolkodást jelenti, amely a környezeti attitüdökben nyilvánul meg. Fontos jellemzője, hogy a természetet hierarchikus rendszernek írja le, méghozzá az emberi társadalmak modellje alapján. Ez amellett, hogy téves összefüggések felszínre kerülését és sztereotípiák elterjedését okozza, negatív környezeti attitüdök kialakulásához is vezet (így például a kegyetlen társadalomfelfogás rávetítése a természetre indítékul szolgál káros beavatkozásokhoz, mintegy legitimálva a romboló cselekményt). Az ember e hierarchiában minden esetben a természet fölé helyezi magát és ezzel tovább erősíti a pusztítás legitimációját, valamint a természeti folyamatokba való mesterséges beavatkozás szükségességét helyezi előtérbe.

A természetközpontúság jelentősen szembehelyezkedik az emberközpontú gondolkodással, ugyanakkor - a számos esetben érvényre jutó (köz)vélekedés ellenére - előbbi nem jelent szélsőségességet, mivel alapvetően nem kirekesztő szemléletet tükröz. Így míg az antropocentrizmus hajlamos a természeti érdekek kirekesztésére, a természetközpontúságról ez nem mondható el (hiszen abban az ember érdekei is megjelennek). Az emberközpontú szemlélet ugyanakkor a jelenlegi közgondolkodásban és a nevelésben egyaránt domináns jellegü, míg a természeti érdekek képviselete, védelme csak „,komplementer” jelleggel jelenik meg. Az emberközpontúságot a jelenkor társadalma hasznosabbnak is ítéli meg (ami értelmezhető önző, túlzottan haszonelvű emberi felfogásként is), míg a természetközpontúságban nem lát sem gazdasági, sem ökológiai, sem környezetegészségügyi/biztonsági hasznot. Az emberközpontúság nemcsak az érdekek 
képviseletében, hanem a társadalmilag elvárt szempontok (és kötelezettségek) rendszerében is domináns (lásd: környezeti hatásvizsgálatok szempontrendszere vagy a környezeti ügyek kimenetele, ahol a természetvédelmi szempontok esetenkénti ,győzelme” mindig nagyobb hírértékkel bír - és később mindig megkérdőjeleződik!).

Komplex rendszerként szemlélve a kérdéskört, fontos megállapítani, hogy pszichológiai-pedagógiai (a tanulási folyamat során érvényre jutó) tényezők egyszerre befolyásolják a különböző környezeti kérdésekre adott válaszokat, az attitüdökre pedig olyan tényezők is hatással vannak, mint az ökológiai, természettudományos, etológiai müveltség; a logikai készségek (e témakörön belül); az evolúciós és fogalmi ismeretek; a sztereotípiák elfogadása; illetve a jelenleg érvényesülő emocionális tényezők, társadalmi hatások. Nyilvánvaló, hogy - mint a legtöbb szemléletkutatásnál - a „háttérváltozók” (család, lakhely, életkor, iskola, egyetemi képzés, képzettség stb.), a személyes élettörténet, egyes meghatározó gyermekkori élmények, illetve a felnőttkori pszichikum (személyiségtípus, társadalmi helyzet, versengési hajlam, emocionális kötődések) szintén kötődnek a környezeti gondolkodáshoz - ha nem is mindig közvetlenül.

\section{Az ökológiai fenntarthatóság ügyében felvetődő antropocentrizmus kimutatásának lehetséges szempontjai a felsőoktatásban}

Antropocentrizmus-vizsgálathoz tartozhat minden olyan tématerület, amely valamilyen módon az emberhez, illetve az ember és természet viszonyának megítéléséhez kötődik. Így válik jelentőssé az ember szerepének tisztázása az élővilágban (pl. esetleges hierarchiák, betagozódás, rokonsági fok - homológia megjelenítése); az evolúcióban (esetleges irányok meghatározása, elhatárolódások az élővilág egyes csoportjaitól vagy magától az evolúciótól); a hatalmi szerepek; az ember rendszertani meghatározása, különbségtételek embercsoportok között; az érdekek tisztázása környezeti ügyek kapcsán (az ember preferálásával); az élővilág belső viszonyainak rendezése emberi szemszögből (ökológiai müködésre vonatkozó sajátos elképzelések) és a társadalmi fogalmak megjelenítése, rávetítése az élővilágra (mint például a „létjogosultság”, „szeretetre méltóság”, „gonoszság”, vagy a „személyiség”).

A felsőoktatásban tanuló első évfolyamos hallgatók környezeti gondolkodásának vizsgálata az előzetes tudást és annak függvényében alakuló attitüdöket képes viszonylag hatékonyan feltérképezni, amelyeket a közoktatás világából „hoztak magukkal”. Ezekből részben következtethetünk a környezeti nevelés sikerességére is, illetve rá tudunk világítani azon hiányosságokra, amelyeket feltétlenül pótolni kell, illetve olyan témákra, amelyeknél egyenesen szemléletváltó oktatásra volna szükség (a konceptuális váltások megalapozása). A végzős évfolyamok eredményei pedig elsősorban azt mutatják meg, mennyire és milyen módon befolyásolta szemléletüket, tudásukat az egyetemen eltöltött idö (a felsőoktatás hatékonysága) és milyen környezeti gondolkodással lépnek ki a munkaerőpiacra (amely döntéseiket jelentősen meghatározza majd). 
Az eddig sikeresen lefolytatott antropocentrizmus-vizsgálatok közül kiemelt jelentőségü volt egy 7 felsőoktatási intézmény 10 szakán végzett, 510 hallgató részvételével készült kutatásom (2010/2011), amely metodológiai szempontból jelentős átfedésben volt egy 2007-es, 2009-es és egy 2013-ban felvételezett, mérnöktanár és pedagógia szakos hallgatók körében készült kérdőíves felméréssel (36+26+19 fö). Így közel 600 fős (több szempontból országosan is reprezentatív) minta segítségével meglehetősen pontos képet sikerült megrajzolni az ember-, illetve természetközpontú gondolkodásról, azok fontos részleteiről. A vizsgálat módszere írásbeli kikérdezéseken alapult (komplex kérdöív: környezeti attitüdöket vizsgáló Likert-skálával, kifejtendő választ igénylő kérdésekkel, egyszerü és összetett választásokkal), az előbb ismertetett minta esetében összesen több mint 80 ezer beérkezett válasz kiértékelését igényelve (matematikai statisztikai eljárások segítségével). Az évfolyamok (elsősök és végzősök), illetve a nemek megoszlási aránya közel 50-50 \%-os volt, utóbbinál pedig a válaszok irányultsága tekintetében a szignifikáns differencia megléte eleve nem volt jellemző (Miklós, 2012).

\section{Az eddigi vizsgálatok ökológiai fenntarthatóságra vonatkozó tanulságai}

A hallgatók környezeti elképzeléseikben olyan sajátos értelmezéseket alkalmaznak, amelyek meghatározzák attitüdjeiket és többségük - a természeti jelenségek müködése kapcsán - az antropocentrikus látásmódot preferálja a tudományosan elfogadott tézisekkel szemben. Környezeti attitüdjeik az ökológiai fenntarthatóság szempontjából nem kielégítőek (vagyis számos környezeti kérdés vagy probléma felvetése kapcsán olyan megoldásokat választanak, amelyek nincsenek tekintettel az ökológiai rendszerek stabilitására, mivel egyoldalúan közelítik meg azokat $\mathrm{s}$ számos lehetséges negatív következményt figyelmen kívül hagynak). Utóbbiak jelentősen függnek ökológiai vagy környezeti müveltségük szintjétől is, amire általában jellemző, hogy az minél alacsonyabbnak mondható, annál antropocentrikusabbak a megnyilvánulásaik. Többségükben túlzott jelentőséget tulajdonítanak az emberi beavatkozások fontosságának is (miközben nem kellően mérik fel azok lehetséges következményeit - ezt más kutatás is megerösíti, lásd Dyehouse és mtsai, 2011). Az antropocentrikus környezeti (s föleg természetszemléletet tükröző) gondolkodás - számos okból kifolyólag, amelyek ismertetésétől helyhiány miatt most el kell, hogy tekintsek - igen adaptív viselkedés az emberi társadalomban, ugyanakkor kevéssé függ a helyi kulturális környezettől (bár utóbbira is látunk példát, lásd: Van Petegem és Blieck, 2006; Boeve-De Pauw és Van Petegem, 2012). Mindeközben a gyakorlati vizsgálatok azt is megerősítik, hogy az embernél észlelhető „megszaladási jelenségek” (lényegében az önkép túlértékelése, amely az antropocentrizmus oka és következménye is lehet) gyakran kulturális természetüek: például „miután a hatalomvágynak nincsen felső korlátja, az emberek korlátlan hatalmat szeretnének, noha éppen etológiai okokból azt funkcionálisan amúgy sem tudnák érvényesíteni” (Csányi, 2006. 244. o.). E jelenséget 
egyértelmüen a külvilágból érkező, hatótényezővé váló ingerek, információk, sztereotípiák, a tudományos ismeretek sajátos értelmezései idézik elő, amelyek adaptívvá teszik az antropocentrikus konstruktumokat a környezeti gondolkodásban (a társadalomban pedig normákká alakulnak).

A környezetvédelmi jellegü, illetve tanárképzéseken résztvevő egyetemi hallgatók nézetei alapján már korábban sikerült kialakítani egy természetmüködési modellt (,az ökológiai antropocentrizmus modellje” - lásd: Miklós, 2011). Ennek fö jellemzője, hogy az antropocentrikus gondolkodás minden természeti (például táplálkozási), ökológiai, evolúciós és rokonsági folyamatot hierarchikus müködésű struktúrában képzel el és az abban foglalt elemek helyét, illetve a befolyásoló tényezőket a sajátos, ugyanakkor jól körülhatárolható elképzelések alapján írja le. A modell és a mérési eredmények rendező elve alapján kialakítható továbbá az ember természeti szerepének tipológiája is, így megjelennek olyan gondolkodású hallgatók, akik az embert „uralkodónak”, „istennek”, a többi élölényhez képest „másnak” írják le - s csak viszonylag kis hányaduk (maximum egyharmaduk vagy még kisebb arányuk a teljes populációhoz képest) tekinti őt a természet részének, s tagadja meg azon esszencialista látásmódokat, amelyek érték alapú különbségeket kívánják előtérbe helyezni.

\section{Az antropocentrikus gondolkodás lehetőségei: az akadály maga lehet megoldás is!}

Az emberközpontú gondolkodás átformálása (illetve az ökocentrizmus felé fordítása) hosszú távú cél, hiszen rendkívül komplex problémakörről van szó és számos akadályozó tényezővel is számolni kell ezen - meglehetősen adaptív rendszer megváltoztatásakor. Ugyanakkor (vagy talán éppen ezért) alkalmazkodni kell a mostani társadalmi helyzethez is: így a hosszú távú cselekvési programok (elsősorban az oktatás, szemléletformálás területén) előkészítése mellett szükségeltetik a jelenkor lehetőségeinek megfelelő kihasználása.

A környezeti etika helyzetbe hozása a köznevelésben (sőt, a felsőoktatásban is!) képes volna elősegíteni, hogy a jövő generáció a legváltozatosabb társadalmi körülmények között - adott esetben az írott szabályok hiánya mellett is környezettudatos normákat alakítson ki és tartson fenn. Egyes jogszabályok kiegészítése már rövidtávon segítheti a beavatkozásra hivatott szakemberek munkáját: az eddigi joggyakorlatban ugyanis megfigyelhető a túlzott „technikai” szemlélet, vagyis pusztán az aktuális probléma megoldására való koncentráltság. Pedig már egy jó törvényi indoklás, a célok világos és sokrétübb indoklása, a jogfilozófiai sík hangsúlyosabbá tétele jobban elösegítené például a természetvédelem eszméjéhez való társadalmi és egyéni kötődést - a Föld többi, velünk együtt élő organizmusa érdekeinek deklarált figyelembevételével. Fontos tényező lehet akár a világvallások segítségül hívása is: antropocentrikusságuk dacára legfőbb előnyük, hogy beépítenek egy spirituális szintet a társadalmi (s azon belül a környezeti) gondolkodásba, ezzel pedig „kipótolják” a 88 
jogszabályokban (ma még) tátongó ürt. Utóbbiról azonban el kell mondani, hogy hatékonysága mellett felsorakoztatható kézzelfogható tudományos eredményeket egyelőre nem látunk - igaz, ellene szólókat sem. Egy amerikai konstruktivista empirikus kutatás szerzője például arról ír, hogy megpróbálta kideríteni, miként lehetne „hasznosítani” a vallásokat az öko-spiritualitáson keresztül a környezeti szemlélet javításához - s bár megállapítja, hogy az eddig vizsgált próbálkozások az attitüdök terén lényegében nem mutattak szignifikáns különbséget a kontrollcsoportokhoz képest, a spirituális megközelítés önmagában nem jelent zsákutcát a probléma megoldásában - ennek pedig egy antropocentrikus környezettudatosság esetleges eredményessége kapcsán lehet jelentősége (Crowe, 2012).

\section{Változtatási lehetőségek a felsőoktatásban}

A tartalmi változtatások szükségessége az elmúlt évek vizsgálati eredményei alapján megkérdőjelezhetetlen. A legkézenfekvőbb lehetőségek a természettudományos alapozó tantárgyak kapcsán merülnek fel, ahol a következő lépések megtétele javasolt:

- Felzárkózatási célú, a közoktatás tananyagát lényegében átismétlő ismeretek integrációja szükségeltetik;

- A tananyag összetétele és oktatásmódszertana vegye figyelembe a hallgatók előzetes tudását (így pl. alapfogalmak tisztázása, egyszerübb fogalmaktól a bonyolultabbak felé való haladás, a konceptuális váltás elérést szorgalmazó módszerek kidolgozása stb.);

- A tananyag tartalmilag igazodjon a hallgatók várható érdeklődési szférájához, használja ki a motivációs lehetőségeket;

- A tananyagban foglaltak és az előadó szakmai hitelessége kerüljön összhangba;

- A követelmények térjenek ki az alapfogalmakra, különösen a környezeti/ ökológiai jellegü kérdések tekintetében;

- A tananyagok összeállításakor alapvető szempont legyen a ráépülés, a szakmai differenciált tananyagok hatékony tartalmi megalapozottságához.

A fentieken túl azonban fontos volna nagyobb figyelmet fordítani a szakmai tantárgyak tartalmi fejlesztésére is, különös tekintettel arra, hogy a fogalmi zavarok, a természeti-társadalmi folyamatok és kölcsönhatások antropocentrikus látásmódja, s a részletekre vonatkozó megnyilvánulások elsősorban ezen tárgycsoportokban kimutathatók. Így a változtatások (konkrétabb példák bemutatásával) a következő témák kapcsán mindenképpen szükségesek:

- Rendszertan: a taxonómiai fogalmak pontosítása, magyarázata (pl. rendszertani egységek elhelyezése, ábrázolása, „magasabb rendü”, „alacsonyrendü” stb. fogalmak félreérthetőségének kezelése);

- Evolúcióbiológia: az evolúcióelmélet pontos tisztázása; az ahhoz tartozó fogalmak (pl. evolúció, természetes szelekció, adaptivitás, alkalmazkodás) 
helyes, tudományos használatának hangsúlyozása; az időben párhuzamosan zajló változások kiemelése, értéksemleges evolúciószemlélet bemutatása stb.;

- Etológia: ember-állat párhuzamok és rokonság az eddigieknél jóval nagyobb hangsúlyozása;

- Ökológia: az ökológiai folyamatok, müködések, összefüggések pontosabb leírása; a hangsúlyok megfelelő elhelyezése a tananyagban; rendszerszemlélet kialakítása analitikus és holisztikus látásmód beépítésével; társadalmi párhuzamosságok tisztázása (a társadalmi müködés természetre való kivetítésének megakadályozásához);

- Vadgazdálkodás: a fogalmak bővebb magyarázata, azok pontosítása; a vadászatban használatos szakkifejezések („dúvad”, „golyóra érett” stb.) félreérthetőségének kiküszöbölése (hangulatkeltés megakadályozása végett is); a természetközpontúság hangsúlyozása;

- Természet- és tájvédelem: a természetvédelmi célok ökocentrikus leírása, magyarázata; környezeti etika beépítése; több szempontú közelítés az egyes problémákhoz (pl. környezeti hatásvizsgálati példákkal).

A környezettudomány komplexitására való tekintettel a felnőttek oktatása során is javasolt áttanulmányozni és figyelembe venni a közoktatásban alkalmazott korszerü környezeti nevelés jellemzöit (például a multi- és interdiszciplináris megközelítések alapján) és azok szerint megválasztani témákat és módszereket (Schróth, 2004). A komplexitás és rendszerszemléletre nevelés jelentősége abban áll, hogy figyelembe veszi az egyes környezeti, társadalmi és gazdasági jelenségek és problémák összefüggéseit és a hallgatókat képessé teszi elsajátított ismereteik mindennapi életükben vagy munkájukban való alkalmazására. A lokalitás és globalitás elvének egyszerre történő megjelenítésével a saját környezetben érzékelhető problémák, tettek következményeit mutathatjuk meg, megfordítva pedig megtalálhatjuk a helyi környezeti gondok mögött húzódó globális társadalmi, gazdasági problémákat. Az analitikus és holisztikus megközelítés segít a világot és a felmerülő kérdéseket egyrészt részekre bontva, elemezve, illetve ellenkező módon, az egészet megbonthatatlan egységként tekintve is vizsgálni.

A felsőoktatásban talán ma még talán szokatlan érzelmi nevelés elősegítése fontos befolyásoló tényezője lehet a hatékonyságnak. Az alternatív gondolkodás, illetve az aktuális és egyszerre jövőbe tekintő látásmód megjelenítése pedig olyan kompetenciaelemmé válhat, amely nélkülözhetetlen a korszerü szemléletü és föleg aktív környezeti polgárok munkaerö-piacra történő kibocsátásához (a hazai lakosság gondolkodásának tekintetében egyébként is komoly probléma a ,passzív környezettudatosság”). Ami pedig a képzések tanterveinek szerkezetét illeti: érdemes nemcsak a tartalmi, hanem az azokat közvetlenül is befolyásoló strukturális felépítést hatékonyabbá tenni, mégpedig úgy, hogy az ne a hagyományos tanulás-felfogási paradigmák követésére, elavult oktatásmódszertan alkalmazására ösztönözze az oktatókat, hanem modern pedagógiai-pszichológiai 
hátterü metodika bevezetésére. Ezen intézkedések kikényszeríthetik az oktatók saját szerepfelfogásának változását is, így nagyobb eséllyel fognak a hallgatókkal közösen dolgozni (pl. problémaorientált tanulás-tanítás, projektoktatás stb.) - még a felsőoktatás expanzióját követően is. Nem közvetíteni fogják a tudást, hanem a tanulási folyamat részévé válnak (illetve annak háttérirányítójává), törekedni fognak az oktatás során többféle interaktív megoldás alkalmazására és koncentrálni a szemléltetésre, hogy a diákokat ezzel is segítsék az önálló felfedezésben. Mindezek - bár időt, energiát és befektetést igénylő cselekvések alkalmasak lehetnek arra, hogy a felsőoktatásban dolgozók és a hallgatók környezeti gondolkodását és az ökológiai fenntarthatóság ügyét egyaránt pozitívan befolyásolják.

\section{Irodalom}

Boeve-De Pauw, J. és Van Petegem, P. (2012): Cultural Differences in the Environmental Worldview of Children. International Electronic Journal of Environmental Education, 2. 1. sz. 1-11.

Crowe, J. L. (2012): Transforming Environmental Attitudes and Behaviours through Ecospirituality and Religion, International Electronic Journal of Environmental Education, 3. 1. sz. 75-88.

Csányi Vilmos (2006): Az emberi viselkedés. Sanoma Budapest Kiadói Zrt., Budapest, 244.

Dyehouse, M., Weber, N. R., Fang, J., Harris, C. A., Tomory, A. és Strobel, J. (2011): First-Year Engineering Students' Environmental Awareness and Conceptual Understanding through a Pilot Sustainable Development Module. American Society for Engineering Education, 1. 897-904.

Lükő István (2003): Környezetpedagógia. Nemzeti Tankönyvkiadó, Budapest.

Miklós Attila (2011): Homo, sapiens? Élet és Tudomány, 66. 7. sz. 202.

Miklós Attila (2012): A környezeti gondolkodás tendenciáinak vizsgálata az egyetemi hallgatók körében, különös tekintettel a nők és férfiak emberkép kialakítását meghatározó sajátosságaira. In: Tóth Péter és Duchon Jenő (szerk.: Kutatások és innovatív megoldások a szakképzésben és a szakmai tanárképzésben. II. Trefort Ágoston Szakmai Tanárképzési Konferencia, Óbudai Egyetem, Budapest, 305-317.

Schróth Ágnes (2004): Környezeti nevelés a középiskolában. Trefort Kiadó, Budapest.

Van Petegem, P. és Blieck, A. (2006): The environmental worldview of children: a crosscultural perspective. Environmental Education Research, 12. 5. sz. 625-635.

Varga Attila (2006): Környezeti kompetenciák fejlesztése a tanítási gyakorlatban. In: Kerber Zoltán (szerk.) Hidak a tantárgyak között. Oktatáskutató és Fejlesztő Intézet, Budapest, 120-131. 